\title{
Floor of the Nose Mucosa Lysis and Labial Abscess Caused by a Bee Sting
}

\author{
Ramón Manuel ALEMÁN NAVAS ${ }^{1}$ \\ María Guadalupe MARTÍNEZ MENDOZA² \\ Henry HERRERA ${ }^{3}$ \\ Helen Piccolo de HERRERA ${ }^{3}$ \\ ${ }^{1}$ Department of Oral and Maxillofacial Surgery, Zacamil's Nacional Hospital, El Salvador, \\ Evangelic University of El Salvador, San Salvador, El Salvador \\ ${ }^{2}$ Latinamerican University, Mexico City, Mexico \\ ${ }^{3}$ Evangelic University of El Salvador, San Salvador, El Salvador
}

\begin{abstract}
Hymenoptera order includes bees, which have a stinging apparatus at the tail capable of delivering venom to the affected tissues. Myocardial infarction, acute renal failure, Necrotizing fasciitis, fatal infection and hemifacial asymmetry, are some of the unusual reactions reported following hymenoptera stings. This paper reports a case of bee sting in the right floor of the nose that mimicked an odontogenic infection affecting the upper lip, canine space and nasal cavity such as in cases of infection secondary to pulpal or periodontal pathology of the anterior teeth. After a thorough clinical and radiographic examination, odontogenic infection was discarded and the diagnosis of floor of the nose mucosal lysis and lip abscess secondary to a bee sting was made. This case was successfully managed with adequate incision, drainage and antibiotics without any further complication. There are several reports of unusual reactions following hymenoptera stings. However, just a few of them referred to infections of local reactions and none of them related to the anatomic location affected in the patient of the present case. Early diagnosis and treatment prevented infection dissemination and the likelihood of tissue necrosis as in previously reported cases of Necrotizing fasciitis.
\end{abstract}

Key Words: hymenoptera, bees, venom, odontogenic infection, unusual reactions.

\section{INTRODUCTION}

The Hymenoptera order (Greek Hymen: membrane; Ptera: alas) includes insects from the families of Vespidae (hornets, wasps and yellow jackets), Apidae (bees) and Formicidae (fire ants). These animals have a stinging apparatus at the tail end of their abdominal segment and are capable of delivering between $100 \mathrm{ng}$ (fire ants) and $50 \mathrm{ng}$ (bees and vespids) of venom (1). Many of the members of this order are commonly found in nature and some of them, especially bees, are also used for commercial purposes. As a result, hymenoptera stings are very common and they usually heal without any complications following minimal treatment (2).

Insect stings can usually result in 1 of 4 outcomes: 1. the most usual one is a local reaction with pain and pruritic urticarial lesion less than $5 \mathrm{~cm}$ in diameter; 2. A large local reaction more than $5 \mathrm{~cm}$ in diameter lasting more than $24 \mathrm{~h} ; 3$. A mild systemic reaction consisting of urticaria, erythema, nausea or diarrhea; and 4. A severe systemic reaction including laryngeal edema, bronchospasm and hypotension (3).

Symptoms following bee stings may be due to immediate or delayed reactions. Immediate reactions, which occur within $2 \mathrm{~h}$, may be subdivided into local and systemic reactions, which may be toxic or allergic and are well documented. Immediate local reactions usually present with erythema, edema and transient pain or pruritis that subsides within a few hours. Reactions that are seen after $2 \mathrm{~h}$ following hymenoptera sting are called delayed reactions and they are not common (2).

Large local reactions, which affect $10-15 \%$ of adults, are considered to be late-phase manifestations of immunoglobulin E (IgE)-mediated hypersensitivity, may involve a whole extremity, and may last up to a week. More serious systemic reactions occur in $0.4-0.8 \%$ of children and $3 \%$ of adults (4). 
Bee venom has various peptide and protein components, some of which are capable of inducing toxic or vasoactive responses. Although tolerance to multiple stings is variable, in most situations 1,500 stings would be required to deliver a lethal dose of venom for nonallergic adult who weighs $70 \mathrm{Kg}$. The fact that $40-50$ deaths per year in the USA are attributed to hymenoptera stings demonstrates the potential severity of hypersensitivity reactions occurring in persons with venom specific IgE antibodies, developed either directly through previous stings or indirectly such as with exposure to bee debris in the beekeeping environment (1). Adrenaline, steroids and antihistamines are the cornerstones to counteract the allergic effects of hymenoptera venom (5).

This paper presents a case of bee sting in the floor of the nose of an adult patient, which mimicked an odontogenic infection secondary to pulpal or periodontal pathology of the anterior teeth, and caused floor of the nose mucosal lysis and a labial abscess.

\section{CASE REPORT}

A 38 year-old male farmer was stung by a bee while he was cutting some bushes in a farm. The bee got inside his right nostril and stung him on the floor of the nose. The patient went to the nearest healthcare center and was treated with antihistamines, steroids and antibiotic, all prescribed by the physician in charge at that time. Despite the initial management, the patient developed a right lip abscess. The patient was referred to

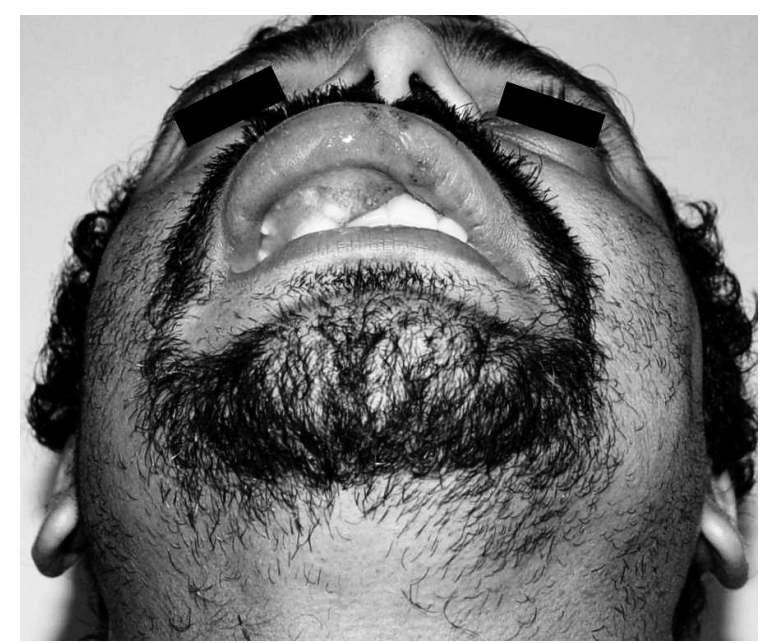

Figure 1. Facial asymmetry secondary to upper right lip edema protruding it outside the normal facial contour. the oral and maxillofacial department because the emergency care unit suspected of an odontogenic infection.

Physical examination revealed a right lip edema causing facial asymmetry (Fig. 1). The lip mucosa presented erythema, edema and spontaneous drainage of frank purulent material along the right side of the oral cavity (Fig. 2). Pulp vitality tests and periodontal probing were done with no signs of pulpal or periodontal pathology of the right anterior and premolar teeth. Nasal examination was achieved with a rinoscope and revealed nasal fluid discharge and a $7 \mathrm{~mm}$ diameter perforation on the floor of the nose when the right nostril was evaluated. Radiographic examination showed no signs of endodontic or periodontal pathology. Based on these clinical and radiological findings, an infection of odontogenic origin was discarded and the diagnosis of floor of the nose lysis and lip abscess secondary to bee sting was made.

No other sites were affected, there was only one sting and there were no evidence of previous reactions to bee stings. No systemic disease was present. The patient signed an informed consent before initiating the treatment procedure. The abscess was debrided and drainaged and the communication between the lip abscess and the floor of the nose perforation was confirmed (Fig. 3). An antiseptic solution was used to irrigate the affected tissues and a drain was left following the damaged tissue to the nasal cavity (Fig. 4A and B). Clindamycin and ciprofloxacin antibiotics, analgesics and chlorhexidine mouthrinses were prescribed.

The affected tissues were cleaned daily. Due to case improvement, drains were withdrawn at the 5 th day.

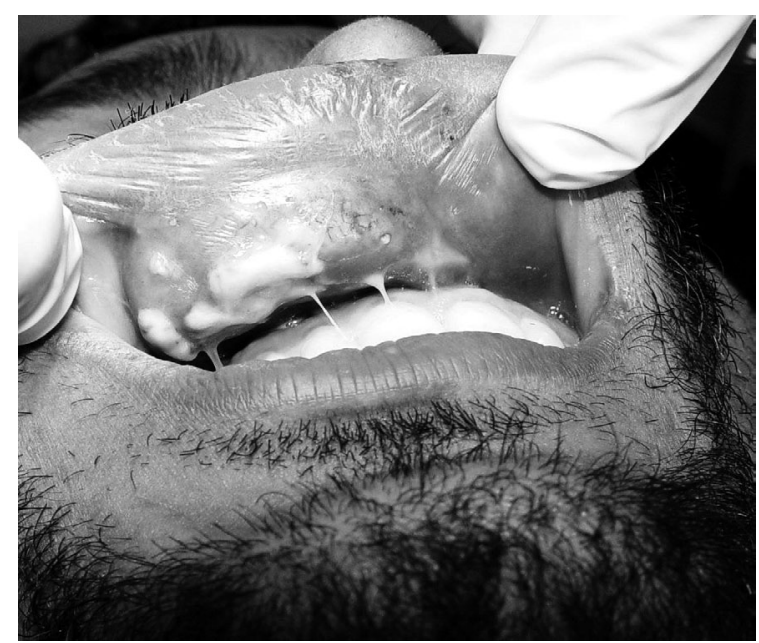

Figure 2. Edema and erythema of lip mucosa. Notice the spontaneous drainage of white purulent material. 
Adequate healing of the lip mucosa and a second intention closure of the nasal perforation were achieved at the 4th week after the initial debridement and drainage, all facial tissues recovered their symmetry (Fig. 5A and B).

\section{DISCUSSION}

Odontogenic infections have two major origins: 1. Periapical origin, as a result of pulpal necrosis and subsequent bacterial invasion into de periapical tissue, and 2. Periodontal origin, as a result of a deep periodontal pocket that allows inoculation of bacteria

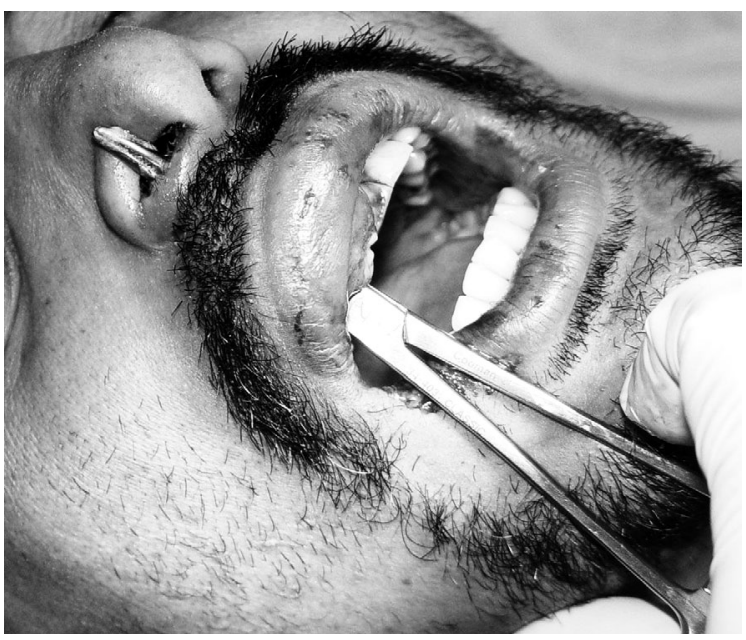

Figure 3. Debridement and drainage of abscess, notice the frank communication of the labial abscess and the right nasal cavity. into the underlying soft tissues. The periapical origin is more common in odontogenic infections. Infections caused by anterior teeth often spread into the upper lip and canine space because the bone layer between the root apex and the alveolar cortical plate in the maxilla is markedly thinner on the buccal side than on the palatal side. When these spaces are occupied, the levator labii superioris and levator anguli oris muscles are affected. Patients with involvement of the orbicularis oris muscle by infection generally show affection of levatory anguli oris muscles. It has also been reported the involvement of the nasal cavity in patients with incisor tooth infections, were symptoms such as pain and nasal obstruction can be found (6). The patient of the present case had the classic sings and symptoms of an anterior odontogenic infection affecting the right lip, canine space and nasal cavity, it was causing displacement of right nasal ala and nasolabial fold, and it was also producing nasal discharge. All these signs and symptoms led the emergency care unit to strongly suspect of a secondary odontogenic infection, which was later discarded by a thorough examination that revealed the absence of pulpal and periodontal pathologies of the anterior and premolar teeth of the affected area.

Bee stings can develop a variety of unusual reactions usually described in isolated case reports, these reactions differ from typical allergic symptomatology and often do not have an apparent cause. From a clinical viewpoint these sting reactions can be characterized by the organ system affected, cardiac, renal or neurologic;
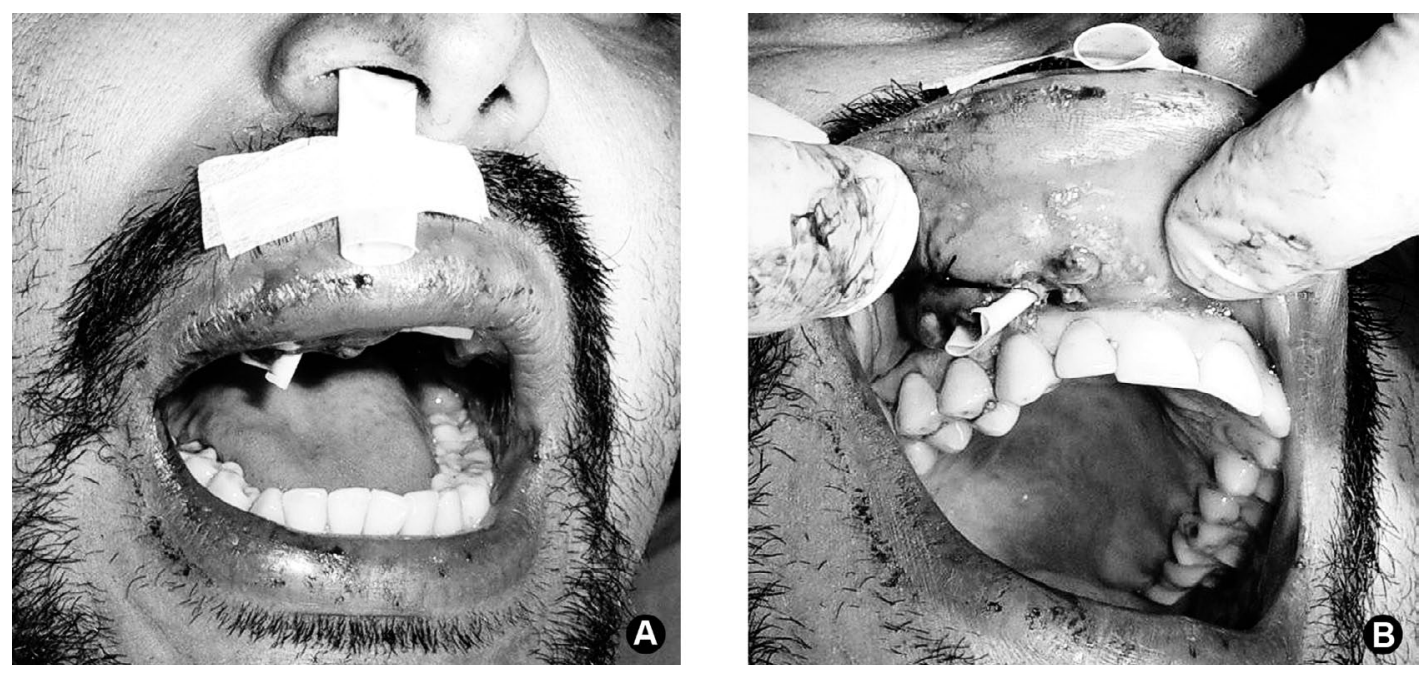

Figure 4. Photographs taken after abscess debridement and drainage. Drain placed into the nasal cavity (A) and exiting in the lip mucosa (B). 
the local or systemic manifestations and the timing of the symptoms in relationship to the sting (7). Acute encephalopathy, Guillain-Barré syndrome, myocardial infarction (8), acute renal failure, nephritic syndrome, rhabdomyolysis, conjunctivitis, cataracts, optic neuropathy (7), Necrotizing fasciitis $(2,9,10)$, fatal infection (11), hemifacial asymmetry (12), are some of the unusual reactions reported following hymenoptera stings.

Feldberg and Kelleway (13) were the first to demonstrate that bee venom has histamine-releasing properties (14). Bee venom contains multiple allergic proteins such as phospholipase A2, hyaluronidase, apamin, and histamin. The most important component is the peptide mellitin, which comprises approximately $50 \%$ of bee venom. Mellitin's high toxicity may cause hemolysis, inflammatory reactions, increased capillary permeability, and smooth muscle contraction. This anphipathic peptide also spontaneously associates with cell membranes, sometimes resulting in membrane disruption and/or lysis. This pronounced cytolytic activity includes mast cell damage (9,14-16). Phospholipase A, another component, is able to degranulate rat mesentery mast cells. Phospholipase A2 enzyme is a potent inducer of IgE antibodies (17).

The histopathological findings of hymenoptera stings include focal spongiosis, hyperplasia and dyskeratosis. Necrosis and ulceration can be seen in the epidermis at the punctum site. Edema of the papillary dermis is also consistent with hymenoptera sting. Superficial and deep perivascular infiltrate, composed primarily of lymphocytes and eosinophils and extending into the deep reticular dermis, is typical of insect sting reactions. Histology may also reveal prominent endothelial cell swelling and extravasation of erythrocytes. Neutrophils and plasma cells may be seen, and in some instances, may be the predominant cell types present. The stinging apparatus may remain in the skin. These remnants can induce the formation of foreign body granulomas or, rarely, epidermoid cysts (18).

Bee sting infections are rare and no field studies have been performed to determine the exact sequence of events that lead to infection of bee stings. Three mechanisms can be suggested. First, the abdomen of the bee is covered with numerous hairs, most of them branched and plumelike, to which pathogenic bacteria could attach. It is known that bees are occasionally attracted by garbage, which may further contaminate them with pathogens. Second, the sting of the bee is a complex organ, consisting of a stylet, two barbed lancets, and a venom sac. When the bee uses its sting, the sting becomes deeply embedded in the skin and briskly advances by alternating the thrusts of both lancets, which, because of the direction of their barbs, can only move forward. Meanwhile, the venom from the sac is injected into the victim. Eventually, the entire stinging mechanism detaches from the body of the bee (which kills the bee); however, because of the automatism of the intrinsic muscles, the lancets continue to advance, and
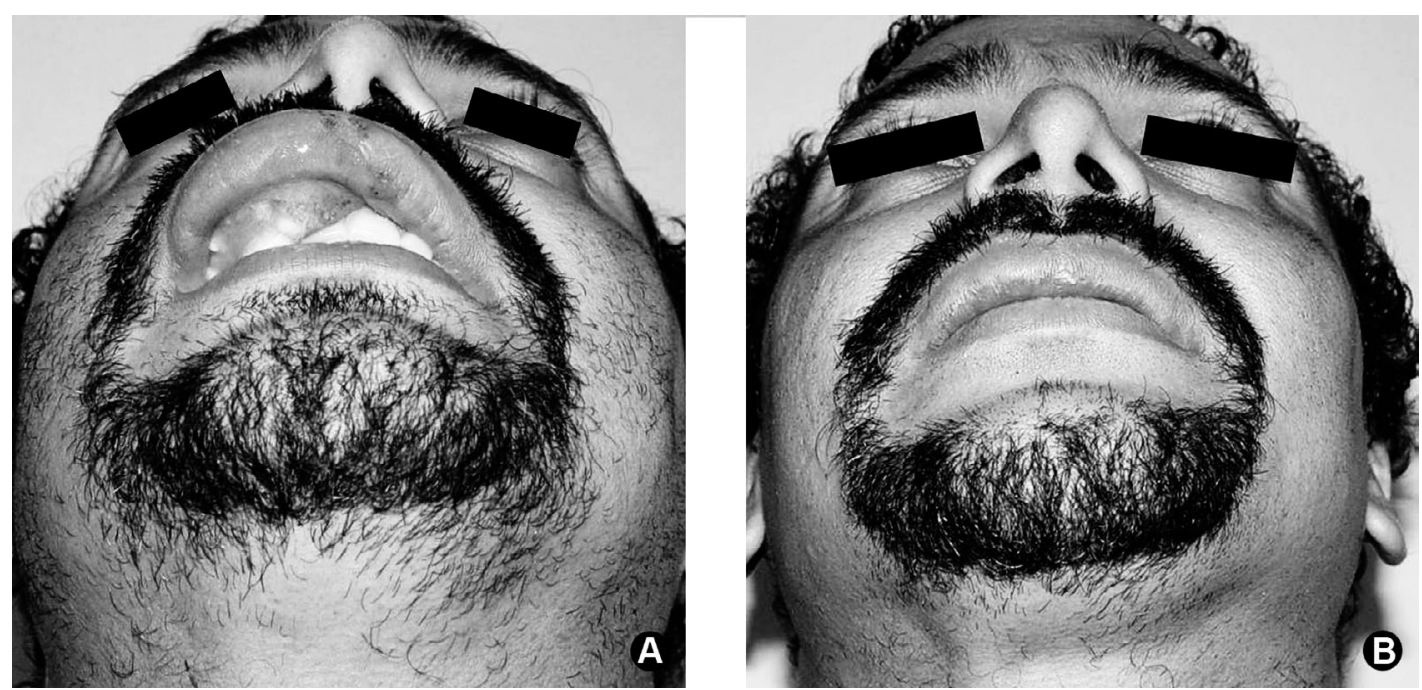

Figure 5. Comparative preoperative and postoperative images. A. Initial photograph. B. Photograph taken 4 weeks after treatment. Note the symmetry of both sides of the face. The patient had an adequate healing of the lip and nasal tissues. 
the venom is continuously pumped. In this manner, any bacteria on either the insect's body or its sting, or on the surface of the victim's skin, can be inoculated under the epidermis. Unless carefully removed, the sting remains in the wound and may facilitate introduction of infection. Third, the venom of the bee contains numerous enzymes and biologically active substances, which produce, among other effects, extensive local swelling and degranulation of mast cells. Itching is usually associated with the sting, and scratching can cause further epidermal injury and intradermal implantation of pathogenic bacteria. Furthermore, the edema surrounding the sting site may temporarily impair lymphatic drainage and reduce clearance of the infection by the immune system $(11,19)$.

An epidemiological study revealed that adult male agricultural workers were at greater risk for having systemic reactions or large local reactions (20). The patient of the present case is a 38-year-old male, agricultural worker who fits in the previous report. There are several reports of unusual reactions following hymenoptera stings, but just a few of them report infections of local reactions and none of them related to the anatomic location affected in our patient. Early and adequate diagnosis of a bee sting that mimicked an anterior odontogenic infection allowed the proper management of the patient avoiding the spread of infection and the likelihood of tissue necrosis as in previously reported cases of Necrotizing fasciitis.

Odontogenic infections are quite common and there is a well established dental protocol to diagnose and treat them. In contrast, non-odontogenic infections affecting the oral and maxillofacial region are rare and represent a real diagnostic and therapeutic challenge for the clinician to solve. Bee stings can display a wide range of reactions, which, if not handled properly can lead to fatal outcomes. Early attention is thus of paramount importance.

\section{RESUMO}

Aordem das himenópteras inclui abelhas, que possuem um ferrão na cauda capaz de de injetar veneno nos tecidos afetados. Fasciite necrosante, infecção fatal e assimetria hemifacial são algumas das reações incomuns relatadas após picada de himenópteras. Este estudo relata um caso de picada de abelha no assoalho da narina direita que simulou uma infecção odontogênica atingindo o lábio superior, o espaço canino e a cavidade nasal, como observado nos casos de infecção secundária após patologia pulpar ou periodontal dos dentes anteriores. Após completo exame clínico e radiográfico, foi descartada a hipótese de infecção odontogênica e foi estabelecido o diagnóstico de lise da mucosa do assoalho da narina e abscesso do lábio, após picada de abelha. Este caso foi tratado com sucesso com adequada incisão, drena- gem e administração de antibióticos, sem outras complicações. Há vários relatos de reações incomuns resultantes de picada de himenópteras, porém poucos são relativos a infecções locais e nenhum se refere à localização anatômica afetada no paciente do caso aqui relatado. Diagnóstico e tratamento precoces preveniram a disseminação da infecção e a possibilidade de necrose tecidual, como já relatado em casos de fasciite necrosante.

\section{REFERENCES}

1. Ellis AK, Day JH. Clinical reactivity to insect stings. Curr Opin Allergy Clin Immunol 2005;5:349-354.

2. Kocer U, Ozer TY, Mete AH, Karaaslan O. Skin and soft tissue necrosis following hymenoptera swing. J Cutan Med Surg 2003;7:133-135.

3. Tome R, Somri M, Teszler CB, Fradis M, Gaitini LA. Bee stings of children: when to perform endotracheal intubation?. Am J Otolaryngol 2005;26:272-274.

4. Moffitt JE, Golden DB, Reisman RE, Lee R, Nicklas R, Freeman T, et al.. Stinging insect hypersensitivity: a practice parameter update. J Allergy Clin Immunol 2004;114:869-886.

5. Junghanss T, Bodio M. Medically important venomous animals: biology, prevention, first aid, and clinical management. Clin Infect Dis 2006;43:1309-1317.

6. Obayashi N, Ariji Y, Goto M, Izumi M, Naitoh M, Kurita K, et al. Spread of odontogenic infection originating in the maxillary teeth: computerized tomographic assessment. Oral Surg Oral Med Oral Pathol Oral Radiol Endod 2004;98:223-231.

7. Reisman RE. Unusual reactions to insects stings. Curr Opin Allergy Clin Immunol 2005;5:355-358.

8. Ceyhan C, Ercan E, Tekten T, Kirilmaz B, Onder R. Myocardial infarction following a bee sting. Int J Cardiol 2001;80:251-253.

9. Ryssel H, Heitmann C, Germann G, Ohlbauer M. Necrotizing fasciitis after a honey bee sting. Eur J Plast Surg 2007;30:11-14.

10. Keskin M, Duymaz A, Tosun Z, Savaci N. Tissue necrosis following a honey bee sting. Ann Plast Surg 2005;55:114-115.

11. Truskinovsky AM, Dick JD, Hutchins GM. Fatal infection after a bee sting. Clin Infect Dis 2001;32:36-38.

12. Coban YK. Mild hemifacial assymetry caused by a single bee sting. Aesth Plast Surg 2005;29:435-436.

13. Feldberg W, Kellaway CH. Liberation of histamine from the perfused lung by snake venoms. J Physiol 1937 17;90:257-279.

14. Rothschild AM, Histamine release by bee venom phospholipase A and mellitin in the rat. Brit J Pharmacol 1965;25:59-66.

15. Remeter A, Lakowicz JR. The aggregation state of mellitin in lipid bilayers. The journal of biological Chemistry. 1986;261:8243-8248.

16. Chao SC, Lee YY. Acute rhabdomyolysis and intravascular hemolysis following extensive wasp stings. Int J Dermatol 1999;38:135-137.

17. Voronov E, Apte RN, Sofer S. Systemic inflammatory response syndrome related to the release of cytokines following severe envenomation. J Venom Anim Toxins 1999;5:5-33.

18. Steen CJ, Janniger CK, Schutzer SE, Schwartz RA. Insect sting reactions to bees, wasps, and ants. Int J Dermatol 2005;44:91-94.

19. Sherman RA. What physicians should know about africanizad honeybees. West J Med 1995; 163:541-546.

20. Fernandez J, Soriano V, Mayorga L, Mayor M. Natural history of Hymenoptera venom allergy in Eastern Spain. Clin Exp Allergy 2005;179-185. 